\title{
Highlight report: hepatotoxicity of triazole fungicides
}

\author{
Wiebke Albrecht ${ }^{1}$
}

Received: 29 August 2019 / Accepted: 2 September 2019 / Published online: 10 September 2019

(c) Springer-Verlag GmbH Germany, part of Springer Nature 2019

Recently, Knebel and colleagues from the German Federal Institute of Risk Assessment in Berlin contributed a study about the mechanisms of action of the triazole fungicides propiconazole and tebuconazole (Knebel et al. 2019). Triazole fungicides act by inhibition of the fungus-specific cytochrome P450 lanosterol-14 $\alpha$-demethylase (Georgopapadakou 1998). The general population is exposed to triazoles via the diet (EFSA 2015). Adverse effects of triazole fungicides include hypertrophy, vacuolization and steatosis of hepatocytes (Schmidt et al. 2016; Heise et al. 2015, 2018). Therefore, the authors studied by which molecular mechanisms triazoles cause hepatotoxicity. For this purpose, they used HepaRG subclones that are deficient in specific nuclear receptors (Knebel et al. 2019). They observed that the knockout of the nuclear receptor PXR but not of CAR ameliorated triglyceride accumulation after incubation with triazoles. However, the studied compounds did not seem to act exclusively by PXR; rather they seem to activate several nuclear receptors, thereby inducing a complex gene expression response, as also observed by Tully et al. (2006) and Hester and Nesnow (2008).

Currently, much effort is invested to improve the possibilities of in vitro systems of hepatotoxicity (Luckert et al. 2017; Grinberg et al. 2014, 2018; Braeuning et al. 2019; $\mathrm{Gu}$ et al. 2018). Traditionally, in vitro systems served to identify the molecular mechanisms responsible for adverse effects (Weng et al. 2014; Frey et al. 2014; Arbo et al. 2016) and more recently have also been used to predict doses and blood concentrations causing an increased risk of toxicity in humans (Albrecht et al. 2019; Sachinidis et al. 2019). This is an approach that often is supported by methods of systems modeling (Ghallab et al. 2016; Hoehme et al. 2010). Knebel and colleagues are to be congratulated for their elegant study

Wiebke Albrecht

albrecht@ifado.de

1 Leibniz Research Centre for Working Environment and Human Factors, Ardeystr. 67, 44139 Dortmund, Germany identifying PXR as a central player in a multi-receptor response induced by triazole fungicides.

\section{Compliance with ethical standards}

Conflict of interest The author declares that she has no conflict of interest.

\section{References}

Albrecht W, Kappenberg F, Brecklinghaus T et al (2019) Prediction of human drug-induced liver injury (DILI) in relation to oral doses and blood concentrations. Arch Toxicol 93(6):1609-1637. https ://doi.org/10.1007/s00204-019-02492-9

Arbo MD, Melega S, Stöber R et al (2016) Hepatotoxicity of piperazine designer drugs: up-regulation of key enzymes of cholesterol and lipid biosynthesis. Arch Toxicol 90(12):3045-3060

Braeuning A, Oberemm A, Heise T, Gundert-Remy U, Hengstler JG, Lampen A (2019) In vitro proteomic analysis of methapyrilene toxicity in rat hepatocytes reveals effects on intermediary metabolism. Arch Toxicol 93(2):369-383. https://doi.org/10.1007/s0020 4-018-2360-3

EFSA (2015) The 2013 European Union report on pesticide residues in food. EFSA J 13(3):4038

Frey O, Misun PM, Fluri DA, Hengstler JG, Hierlemann A (2014) Reconfigurable microfluidic hanging drop network for multi-tissue interaction and analysis. Nat Commun 5:4250

Georgopapadakou NH (1998) Antifungals: mechanism of action and resistance, established and novel drugs. Curr Opin Microbiol 1(5):547-557

Ghallab A, Cellière G, Henkel SG et al (2016) Model-guided identification of a therapeutic strategy to reduce hyperammonemia in liver diseases. J Hepatol 64(4):860-871. https://doi.org/10.1016/j. jhep.2015.11.018

Grinberg M, Stöber RM, Edlund K et al (2014) Toxicogenomics directory of chemically exposed human hepatocytes. Arch Toxicol 88(12):2261-2287. https://doi.org/10.1007/s00204-014-1400-x

Grinberg M, Stöber RM, Albrecht W et al (2018) Toxicogenomics directory of rat hepatotoxicants in vivo and in cultivated hepatocytes. Arch Toxicol 92(12):3517-3533. https://doi.org/10.1007/ s00204-018-2352-3

Gu X, Albrecht W, Edlund K et al (2018) Relevance of the incubation period in cytotoxicity testing with primary human hepatocytes. 
Arch Toxicol 92(12):3505-3515. https://doi.org/10.1007/s0020 4-018-2302-0

Heise T, Schmidt F, Knebel C et al (2015) Hepatotoxic effects of (tri)azole fungicides in a broad dose range. Arch Toxicol 89(11):2105-2117. https://doi.org/10.1007/s00204-014-1336-1

Heise T, Schmidt F, Knebel C, Rieke S, Haider W, Geburek I, Niemann L, Marx-Stoelting P (2018) Hepatotoxic combination effects of three azole fungicides in a broad dose range. Arch Toxicol 92(2):859-872. https://doi.org/10.1007/s00204-017-2087-6

Hester SD, Nesnow S (2008) Transcriptional responses in thyroid tissues from rats treated with a tumorigenic and a non-tumorigenic triazole conazole fungicide. Toxicol Appl Pharmacol 227(3):357369. https://doi.org/10.1016/j.taap.2007.10.030

Hoehme S, Brulport M, Bauer A et al (2010) Prediction and validation of cell alignment along microvessels as order principle to restore tissue architecture in liver regeneration. Proc Natl Acad Sci USA 107(23):10371-10376. https://doi.org/10.1073/pnas.0909374107

Knebel C, Buhrke T, Süssmuth R, Lampen A, Marx-Stoelting P, Braeuning A (2019) Pregnane X receptor mediates steatotic effects of propiconazole and tebuconazole in human liver cell lines. Arch Toxicol 93(5):1311-1322. https://doi.org/10.1007/s00204-01902445-2

Luckert C, Schulz C, Lehmann N et al (2017) Comparative analysis of 3D culture methods on human HepG2 cells. Arch Toxicol 91(1):393-406. https://doi.org/10.1007/s00204-016-1677-z
Sachinidis A, Albrecht W, Nell P, Cherianidou A, Hewitt NJ, Edlund K, Hengstler JG (2019) Road map for development of stem cellbased alternative test methods. Trends Mol Med 25(6):470-481. https://doi.org/10.1016/j.molmed.2019.04.003

Schmidt F, Marx-Stoelting P, Haider W et al (2016) Combination effects of azole fungicides in male rats in a broad dose range. Toxicology 355-356:54-63. https://doi.org/10.1016/j.tox.2016.05.018

Tully DB, Bao W, Goetz AK et al (2006) Gene expression profiling in liver and testis of rats to characterize the toxicity of triazole fungicides. Toxicol Appl Pharmacol 215(3):260-273

Weng MK, Natarajan K, Scholz D, Ivanova VN, Sachinidis A, Hengstler JG, Waldmann T, Leist M (2014) Lineage-specific regulation of epigenetic modifier genes in human liver and brain. PLoS One 9(7):e102035. https://doi.org/10.1371/journal.pone.0102035

Publisher's Note Springer Nature remains neutral with regard to jurisdictional claims in published maps and institutional affiliations. 